\title{
Bill Murray and Wes Anderson, or the Curmudgeon as Muse
}

\author{
Colleen Kennedy-Karpat
}

\begin{abstract}
A s Melena Ryzik joked in a report from a Golden Globes after-party, "Ain't no party like a Bill Murray party, because a Bill Murray party don't stop." Although it was meant to encapsulate the antics of a single evening, Ryzik's observation resonates beyond one star-studded gala into the arc of Murray's entire career, and director Wes Anderson has certainly enjoyed a Bill Murray party that seems like it won't soon stop.

Over the course of six (soon to be seven) feature films, Anderson and Murray have formed a core partnership with a rotating additional cast of actors, screenwriters, and technical collaborators. Anderson's tendency to partner with the same people time and again has created an exceptionally close-knit cinematic family, united by the pursuit of his overarching vision. Murray was the first true star to work with Anderson, playing the disgruntled, self-made millionaire Herman Blume in Rushmore (1998), the studio follow-up to Anderson's breakout feature, Bottle Rocket (a film Murray claims never to have seen). ${ }^{2}$ Since Rushmore, Murray has been involved in all of Anderson's feature films, with roles ranging in importance from the eponymous oceanographer in The Life Aquatic with Steve Zissou (2005) to a nameless businessman in The Darjeeling Limited (2007). Anderson's casting of Murray, though grounded in the actor's previous work, shows subtle yet significant modifications to his star persona that other directors have since adopted. By mapping out new, more "melancomic" terrain (to borrow Deborah J. Thomas's term), Anderson pushed Murray's persona to evolve beyond the high-concept setups of Hollywood comedy to focus instead on quotidian struggles involving family, love, and finding one's place as an aging boomer in a changing world. ${ }^{3}$
\end{abstract}


Behind the scenes, too, Murray has shaped the way that Anderson's films are made and marketed to fans, with DVD releases and auteur discourse that highlights the teamwork between the director and his favorite muse. This seemingly required inclusion of Murray in both the films and their digital afterlife gestures toward a subversion of the term auteur as applied to Anderson; far from a lone genius behind the camera, Anderson's collective of cinema professionals-with Bill Murray as its core performer-offers an Indiewood variation on Thomas Elsaesser's likening of twenty-first-century auteurs to military officers, directing their troops according to a concept that stretches across multiple films and even multiple media platforms (288). Before examining more closely how Murray's ubiquity in the Andersonian universe challenges the notion of the auteur, we should explore the trajectory that led him to this partnership in the first place.

Bill Murray began his acting career in the late 1970s, first on the small screen, most notably Saturday Night Live, before appearing in feature films. In the 1980s, Murray played a pothead groundskeeper in Caddyshack (Ramis, 1980), an unlikely soldier in Stripes (Reitman, 1981), a skeptical confidant in Tootsie (Pollack, 1982), and, perhaps most famously, a smartmouthed policeman of the paranormal in Ghostbusters (Reitman, 1984) and Ghostbusters II (Reitman, 1989). At this early stage of his career, Murray's rare excursions outside comedy underwhelmed both audiences and critics; in 1984, The Razor's Edge (Byrum) featured Murray as a dramatic lead, but critical and popular responses ranged from tepid to hostile. When Murray returned to mass-market comedy in the early 1990s, he kicked off a period during which, as Ryan Gilbey asserts, his fans "stopped having to apologize for the films in which their idol appeared," with roles that combined humor with serious themes in more plausible, even pointedly philosophical ways (27). Groundhog Day (Ramis, 1992), one of Murray's most enduring performances, uses its core conceit to venture into startlingly dark territory, with a somber premise that complements Murray's inherent resistance to schmaltz. Summarizing Murray's comic appeal around this time, Pauline Kael declared that "we like Murray because of his oddity and because he seems so fundamentally untrustworthy. There's something grungy to the soul that he knows how to work and it's wonderful" (Gilbey 53).

Murray retained this tainted-soul image into the late 1990s, when his attention turned toward less-commercial projects, including Rushmore. In Anderson's films, Murray's essential "grunge" defies the polished dialogue and meticulous mise-en-scène, a contrast that makes him a surprising yet compelling figure within the Andersonian universe. Anderson and his coauthors write with specific actors in mind, and for Rushmore, Bill Murray inspired the character Herman Blume before he ever signed on to play 
him. ${ }^{4}$ While Blume neither reverses nor rejects the preexisting Murray persona, Anderson and coauthor Owen Wilson introduce significant innovations. Before Rushmore, Murray's leading roles either burst forth in medias res like the robbery in Quick Change (Murray and Franklin, 1990), or they get a flimsy backstory: lingering romantic regret in Scrooged (Donner, 1988), a persistent social maladjustment in What About Bob? (Oz, 1991). These stock characters all but require Murray's presence to make them credible: of course Bill Murray would dress as a clown to rob a bank before attempting the perfect getaway, of course Bill Murray would be a cutthroat TV boss, of course Bill Murray would have psychological problems. But it takes Bill Murray to sell these characters to the audience. Likewise, his supporting roles, such as the skeptical best friend in Tootsie, are indelibly shaped by his idiosyncrasies. In roles both major and minor, many directors also relied on Murray's gift for improvising dialogue. ${ }^{5}$

Despite his recognized talent for invention under pressure, what convinced Murray to work with Anderson on Rushmore was his conviction that the script would not require his comic enhancement. He explained to Charlie Rose that the screenplay "was so precisely written, I mean you could tell that [Anderson] knew exactly what he was doing. He knew exactly what he wanted to make, exactly how he wanted each scene to go. I've never really seen [a script] that was that precise. I looked at it and I went, this one's different. He knows exactly what he's doing, and I'll go with it. Anybody who can write that well, I feel confidence in."' The clarity of vision Murray saw in Rushmore extends to the source of his character's discontent. Like nearly every Murray antihero, Herman Blume is miserable. But unlike the vaguely defined, yet definitively performed malaise that motivates Grimm in Quick Change, John in Stripes, and Phil in Groundhog Day, Rushmore takes pains to establish why Herman Blume is miserable. His marriage is foundering. He despises his sons. He has achieved much, yet feels empty. And then, he finds an unlikely antidote to this midlife ennui: his sons' precocious classmate Max Fischer (Jason Schwartzman), whose friendship offers Blume a meaningful human connection.

In Murray's estimation, it speaks volumes about Blume that, after bootstrapping his way to millions, he responds so strongly to the schemes of a plucky high schooler: "That's a guy who wants to start over again. He wants to cut off the limb he's on and go back to the root somewhere; he wants to get back down. And I've had that feeling many times, that I could cut it off and start over." 7 Blume longs to return (if not regress) to the beginning and take another shot at life, seeking a spiritual and emotional rebaptism to match the literal immersion at his sons' pool party in an early sequence. Several visual and emotional parallels link this scene in Rushmore, which introduces Blume, to Mike Nichols's 1967 film The Graduate, a connection that 
Donna Peberdy explores (67). However, Peberdy elides one very important distinction between Ben Braddock (Dustin Hoffman) and Herman Blume: Braddock might be reluctant to launch himself into adulthood, but once he does, he will charge forth for the first time. Blume, on the other hand, has long since forged his path; now facing midlife, he finds that this trajectory has brought at least as much heartache as success. Hesitating at the start is not the same as yearning to take it all back, and starting over can be conceived only after the first attempt has been thoroughly botched. Still, what these characters share is more significant than what separates them: a 21-year-old Braddock in 1967 would be roughly the same age as Blume in 1998. These characters both belong to the baby-boomer generation, even if these films capture very different moments in their lives.

In Rushmore, for the first time, Murray allows his star persona to be hitched to specifically midlife moments of strife. As Peberdy explains, Murray began to eschew his mugging, "goofball persona" in pursuit of more subdued expressions of angst, and he began to win critical acclaim for his portrayal of the crises of white, male middle age (71-73). In Rushmore and the films that followed it-whether directed by Anderson or one of his contemporaries-Murray may have come of age, but this has not solved his problems so much as created new ones. Murray points out that Herman Blume was his first character "who was old enough to have children, in a way. I mean, I was old enough, always, probably, but it was the first one where I was definitely somebody who could've been relating to his own son." ${ }^{8}$ Recognizing this shift in social station and its concomitant responsibilities marks an important transition for Murray, who in Rushmore and later Anderson films moves beyond romantic coupling to delve instead into the much thornier negotiations of family life.

The life of a family man requires different skills than those involved in seduction. In the 1980s and '90s, many of Murray's roles figure him as a playboy, or at least a character whose narrative's closure involves gaining, regaining, or maintaining a heterosexual partnership (e.g., Scrooged and Groundhog Day), sometimes alongside meaningful homosocial bonds (e.g., Stripes, the friend role in Tootsie). Importantly, these romantic plots and subplots do not revolve around eliminating a rival; when it comes to love, these comedies make Murray his own worst enemy. In contrast, Anderson situates Murray as potentially attractive to women, but never prioritizes the ups, downs, and triangulations of this attraction in his narrative arc. Other relationships always take center stage. Walt Bishop's troubled marriage in Moonrise Kingdom serves as a backdrop to the budding love between his daughter and a runaway Khaki Scout, pitting the singular dedication of young love against the tedium and tribulations of a long-term, adult partnership. In Rushmore, Blume's pursuit of Miss Cross takes second place to 
his friendship with Max, although these romantic overtures abruptly turn Max against him. In Life Aquatic, Eleanor's departure rekindles the professional rivalry between Zissou and her ex-husband Alistair Hennessey (Jeff Goldblum), a romantic defeat compounded by Zissou's unrequited crush on Jane (Cate Blanchett), who prefers his alleged son, Ned (Owen Wilson). Both Life Aquatic and Rushmore refuse to place the focus on Murray's character's failure to tend to his marriage while fruitlessly pursuing a new love interest; instead, each film gives far more attention to the intergenerational relationship between two men and how it interacts with these romantic exploits.

As they navigate the long haul of marriage, Murray's characters often discover that their wives have been unfaithful, even if they themselves aren't the cheating kind. Blume's wife in Rushmore flirts with a young man at the pool party before kicking Blume out of the house over his affair with Miss Cross; after an early sequence in Life Aquatic suggests that Zissou has been a fairly unapologetic philanderer, he tries in vain to appease both his wife and his new (unrequited) flame. But in The Royal Tenenbaums, Raleigh St. Clair shows calm devotion to his troubled, much younger wife, Margot (Gwyneth Paltrow), a dedication that veers into despair after a detective uncovers her myriad affairs. Here, Raleigh emerges as the victim, not the perpetrator, with his only consolation prize a newfound public recognition for his work. As both a cuckold and an indifferent-or perhaps ambivalent-father, ${ }^{9}$ Walt Bishop in Moonrise Kingdom recombines many of the defining characteristics of Murray's previous work with Anderson. Walt doesn't need a private eye to reveal his wife's affair; moreover, the fissures in their marriage exceed this obvious infidelity: twin beds, intrahousehold communication via megaphone, and his own simmering rage. Shirtless, a bottle of wine in hand, Walt fishes an ax out of a closet and crosses the frame as he announces to his three young sons, "I'll be out back. I'm gonna go find a tree to chop down." When the search party finds Suzy and Sam's campsite, Walt does not tap gently on the kids' tent door-he rips the whole thing up from its rigging.

This physical manifestation of private turmoil, in Moonrise as in other Anderson films, introduces a measure of sad-sack slapstick to which Murray's persona is well suited. In Rushmore, his fleeting bursts of physical humor threaten to disrupt Anderson's careful mise-en-scène: Blume falling to the ground after climbing a fence, Blume jogging out of the frame after an encounter with Miss Cross, Blume flailing in a swarm of bees that Max has surreptitiously released into his hotel room. Life Aquatic's island rescue sequence features physical humor involving multiple characters, but Murray's battles with leeches and a staircase trump them all. James MacDowell notes that when a film's comic performances are generally restrained, 
moments like these "often surprise with [their] suddenness and borderline-surreal incongruity," a blend of styles that he identifies as a mark of the "quirky" (8-9). According to MacDowell, Wes Anderson is a prime example of this sensibility, making Murray's ability to combine physical comedy with deadpan delivery a key asset in the conception and execution of the director's vision. Indeed, Peberdy locates the term "deadpan" in a number of reviews of Murray's performances, indicating its importance to his overall persona. But the effort to humanize this element of Murray's image sets Anderson's work apart from other directors, who until Rushmore had deployed his comedic talents to very different ends.

As for his own cinematic influences, Anderson tends to wear them on his sleeve. Much of his own self-criticism refers to favorite films and filmmakers that reveal a clear predilection for European cinema: Louis Malle, François Truffaut, Roman Polanski, Luis Buñuel, Bernardo Bertolucci. Few Americans or Asians appear in his canon, although he mentions Stanley Kubrick and Orson Welles, and intertextual references in Darjeeling intimate a familiarity with Bollywood. Self-consciously aligning his tastes with the Continental aesthetic, Anderson named his production company American Empirical Productions, ironically recalling the European arthouse tradition that sprouted just as the continent's colonial empires had finally begun to break apart. From an aesthetic perspective, at least, Anderson's films "see" geography through this trans-Atlantic lens.

Even Anderson's approach to America differs from that of, for example, Alexander Payne, a fellow Indiewood director whose films wryly yet sympathetically observe specific corners of America and the people who inhabit them. Payne's vision falls in closely with regional ethnic stereotypes: overwhelmingly white for the Midwest of About Schmidt (2002), appropriately heterogeneous for the Hawaii of The Descendants (2011). In contrast, Anderson takes places that could be represented as culturally or ethnically narrow and carefully broadens them to emphasize diversity. The titular private school in Rushmore, filmed at an actual school in Texas where coauthor Owen Wilson spent some of his formative years, features the British Miss Cross (Olivia Williams) and a Scottish school bully (Stephen McCole). Scottish actor Brian Cox was sought out for the role of headmaster Dr. Guggenheim, although the character's national origins are unclear. The groundskeeper, Mr. Littlejeans (Kumar Pallana), and Max's geometry teacher (Deepak Pallana, son of Kumar) point to a local, integrated South Asian population. However indirectly, these characters all embody pieces of the British empire, introducing connotations of ambition and Old World prestige that exaggerate the stereotypes that would normally populate a school like Rushmore Academy. In contrast, once Max enrolls at the local public high school, he finds a wider range of ethnic diversity (but no foreign 
accents). In the midst of this heterogeneity, Herman Blume presents an archetypal iteration of the American dream; Blume, once a scholarship student like Max, has gone on to build his own industrial empire. However, his emotional turmoil underscores the instability of this achievement, and part of his angst could stem from the bewildering forces of globalization and multiculturalism that threaten to push middle-aged white men out of their familiar positions of power. Blume's wealth clearly matters to the narrative, ${ }^{10}$ but, less obviously, so does his whiteness.

Even Blume's nationality becomes a factor that singles him out in an environment like Rushmore, and casting a famous comic actor like Murray in the role underscores something specifically American in his appeal. Murray's attitude, his manner of speaking, and his star persona all took root in American comedy, and in the global film industry, comedy tends to travel less well than dramatic fare. The Royal Tenenbaums downplays Murray's cultural specificity by situating him among kindred folk, and Rushmore at least grants him home-field advantage, but the Mediterranean setting of Life Aquatic underscores the sensation that Murray is literally charting unfamiliar territory. Life Aquatic brought Wes Anderson's cast and crew out of America for the first time, filming at Italy's legendary Cinecittà studios. Producer Barry Mendel emphasizes how this location affected the process: "There's something very Italian and European which has kind of crept into this film and made [. . .] a unique fabric that wouldn't feel the same if it were made in America. [...] That [European] flavor is actually a powerful force in the film." 11 Yet this European veneer never subsumes Bill Murray's Americanness. Like Max at Rushmore Academy, Zissou is surrounded by foreign and/or ethnically marked characters: the German Klaus Daimler (Willem Dafoe), the British Jane Winslett-Richardson (Cate Blanchett), the Brazilian Pelé Dos Santos (Seu Jorge), the Sikh cameraman Vikram (Waris Ahluwalia), and so on. Even Zissou's wife, Eleanor, gloriously incarnated by Anjelica Huston, may be American (we never find out), but wherever she is, she seems to feel at home in a way her husband apparently does not. Only Ned Plimpton (Owen Wilson) shares Zissou's evident Americanness, although his Air Kentucky affiliation, his Southern drawl, and his genteel manners underscore the idea that region, not nation, better encapsulates his identity.

Moving even farther afield of the Americas, The Darjeeling Limited emphasizes still more clearly the foreignness of the setting relative to its protagonists, even though here Murray's appearance amounts to little more than a cameo. The opening sequence shows Murray in the backseat of a tiny cab, zooming through Indian streets crowded with pedestrians, animals, and other obstacles both living and inanimate. Alternating anxious glances at his watch with even more anxious glances at his surroundings, Murray 
is clearly in a hurry, and the driver does his best to oblige. But when the cab pulls into the train station, Murray sprints away without paying, barely looking back as he cuts into the line at the ticket window. Throughout his career, Murray has frequently played men of privilege, ${ }^{12}$ but in Darjeeling this privilege takes a highly specific form: the "ugly American" abroad. Mining the same vein, Jim Jarmusch cast Murray in his enigmatic quest film The Limits of Control (2009) as an ambiguously evil businessman, one figure in a cast of characters named according to national, descriptive, and metonymic identifiers: Lone Man (Isaach de Bankolé, the protagonist), Créole, French, Waiter, Blonde, Guitar, Mexican, Driver. As for Murray, his character is, simply, American. Reduced to a nationality, yet incarnated by a star, this character and this casting allow Jarmusch to distill Murray's identity down to a specific cultural core. ${ }^{13}$

While Anderson has made strong use of this particular nuance in Murray's updated star image, he did not invent this twist. Before Life Aquatic, Sofia Coppola's Lost in Translation (2003) cast Murray in an ambiguously romantic friendship between two Americans in Japan, a relationship with echoes of Rushmore: a pair of loners, decades apart in age, strike up a friendship at a fraught moment in each of their lives. Of course, Coppola's film moves this rapport in a new direction by making the younger character a woman (Scarlett Johansson), thus introducing the notion of heterosexual romance, and by setting the story in Tokyo. This cultural estrangement amplifies the characters' sense of isolation, imposing it from without even as it wells up from within. The fact that Murray plays a prominent actor on the decline-with a name, Bob Harris, that seems like an alternate-universe rendering of his own-also lends this character a more overt suggestion of autobiography than Anderson put into Herman Blume or Raleigh St. Clair. Anderson's personal and professional connections to the Coppola familyhis Moonrise Kingdom cowriter, Roman; director, Sofia (Roman's sister); and their cousin, Jason Schwartzman — suggest that they share a similar outlook on Bill Murray as a star. From outside this family circle, Jarmusch also emphasizes feelings of loss and alienation in his use of Murray, and all of their work has collectively reinforced and extended his post-Rushmore persona.

Beyond tailoring Murray's star image for a new kind of film, Anderson has also drawn inspiration from his presence behind the camera. Even when Murray plays a minor role in the ensemble, copious DVD extras suggest his near omnipresence behind the scenes. These featurettes, as Devin Orgeron explains, have helped construct an image of Anderson as a "nottoo-authoritative" auteur, who makes "his dependence on others a proud thing, the defining feature of his particular brand of authorship" $(56,59)$. In several cases, Murray is interviewed at least as extensively as Anderson, 
and while sharing the virtual space of DVD extras may seem like a purely practical move, as Timothy Corrigan explains,

the interview ... is one of the few extratextual spaces that can be documented where the auteur, in addressing fans and critical viewers, engages and disperses his or her own organizing agency as an auteur. Here, the standard directorial interview might be described according to the action of promotion and explanation; it is the writing and explaining of a film through the promotion of a certain intentional self, and it is frequently the commercial dramatization of self as the motivating agent of textuality. $(52)^{14}$

If Anderson openly shares something as sacred (and typically self-aggrandizing) as interview footage, this alone makes a strong case for considering him as a different kind of auteur. Taking inventory of these DVD extras (especially, though not exclusively, those on Criterion Collection releases), it becomes clear that Anderson's "commercial dramatization of self" involves reenacting and reinforcing the collaborative spirit of his filmmaking. While the director himself is neither reclusive nor self-effacing in these assembled extras, as Orgeron suggests, these featurettes strive not to create a singular vision in the classic auteurist mold, but rather emphasize how many people both behind and before the cameras have united under the Anderson brand to create the film in question. In addition to stars, these glimpses behind the scenes also emphasize writing and production design, neither of which are usually acknowledged as part of a team effort in the context of auteurist aesthetics.

While writers and designers get an unusually bright spotlight in the Andersonian collective, the industry focus on stars (including the treatment of auteur directors as a particular kind of star) makes their inclusion de rigueur. Considering that Anderson has directed only one feature film without him-Bottle Rocket, his first-Bill Murray has played a more consistent role than anyone in shaping the Andersonian aegis for audiences and fans. Before Anderson had met Murray, the actor's freewheeling reputation caused some trepidation. As Anderson tells Charlie Rose,

I was a little terrified, because I'd heard stories about him. [. . .] You know that he's a guy who can walk into a crowd of people and take control of it, in a way that I never could. He's really funny; everyone loves him already [. . . ] And then I'd also heard about him throwing someone in a lake on one thing, and if he didn't like the situation, he's going to fix it his way. So I was scared before I met him.

But once they came face-to-face, Anderson realized that Murray's charisma could be channeled and that Murray was fully prepared to let him 
channel it. Anderson continues, "As soon as I met [Murray], I felt so comfortable with him; I felt he was so intelligent, and he was so clearly getting involved with us for all the right reasons, and he wanted to do what we wanted to do. And then I just realized that everything I was afraid of-I can use all that stuff. He's going to bring that to this, and we can benefit from it."

While Anderson painstakingly crafts his vision down to the tiniest detail, he concedes that he expects the actors to add a measure of unpredictability to the mix. ${ }^{15}$ Murray's loose approach exemplifies this premeditated randomness; in an interview conducted after filming Tenenbaums, Murray admits that he prefers "to play a different way every time. I want to get my money's worth. I want to work out. Before, I felt like I had to be pretty responsible and professional, because I don't know how these people [costars] work, but then I realized, you know what, they're going to do it their way no matter what, so I'm just going to keep doing it my way. That's when I finally just had fun."16 This shake-it-up strategy held fast when he took on a meatier role as Steve Zissou in Life Aquatic: "Every take is different," Murray says. "It's fun for me to just go, just let the lines fly." ${ }^{17}$ Zissou's central position in the narrative naturally makes Bill Murray a mainstay in the extras that accompany the film's Criterion DVD releaseand including Steve Zissou in the title underscores the character's role as an old-school auteur, one whose authority presides over the making and interpretation of a film, making Murray's role in Life Aquatic a kind of parodic anti-Anderson. ${ }^{18}$

Anderson praises Murray for being "quick" to understand the requirements of a scene, declaring: "I've never met anybody else like him. [. . .] He really has an effect on people, and he has an effect on a group of actors, and he has an effect on a crew of people who will just never forget him." 19 Murray's costars confirm Anderson's statement, and the "Starz on the Set" featurette included with Life Aquatic shows them chiming in with firsthand impressions. Cate Blanchett says that Murray "galvanized everyone," a sentiment echoed by Willem Dafoe, who adds that "Bill's been an important support" to Anderson's work. Murray also connected with the crew who filmed "This Is an Adventure," a featurette helmed by cinematographer and documentarian Albert Maysles. In their acknowledgments for "This Is an Adventure," the crew folds a number of inside jokes into their somewhat cryptic, penultimate message, which is ostensibly aimed at Murray: "Super Duper Shout Out to Bill for taking us in and making us feel at home so far away. We learned a lot. P.S. Sorry about the foot thing during the World Series." Meanwhile, their final, far less intimate acknowledgment recognizes Anderson: "Thanks for letting us into your precious world. It's always an adventure." A sincere sentiment, to be sure, yet the message to the man 
running the show lacks the camaraderie of the "Super Duper Shout Out" dedicated to its star. Anderson's early remarks about Murray's magnetism shine through in this expression of fraternal respect.

The extras on Anderson's latest release, Moonrise Kingdom, ${ }^{20}$ show a disproportionate focus on Murray relative to his screen time in the film, including the "Set Tour with Bill Murray" that lets him loose behind the scenes. The contrast between Murray's quick, anarchic wit and the scrupulously constructed set pieces underscores yet again how Murray's signature contribution to an Anderson film lies precisely in their disparate approaches to filmmaking: Murray's intelligent chaos meets Anderson's cultivated imagination, both on-screen and on set, both within Murray's characters and within Murray the star. Their continuing partnership ${ }^{21}$ showcases Anderson's uniformity of vision even as it confirms Murray's vital role in the authorial team recognized under the name "Wes Anderson." Bill Murray may seem like an unlikely muse, but working with Anderson has infused his star persona with the failed ambitions and squandered potential of Herman Blume, Raleigh St. Clair, Steve Zissou, even the anonymous suit running late for his Indian train. These themes are Anderson's, but this man's face is always Murray's.

\section{Notes}

1. Tom Shone's profile of Murray in the Guardian (December 7, 2012) explores how Murray's effervescent sociability spills into fans' lives as well.

2. Murray has repeated this claim in a number of sources, perhaps most insistently in his interview with Charlie Rose on the Criterion DVD release of Rushmore, during which he admits having received, but never viewed, multiple DVD copies of Bottle Rocket before accepting the role based solely on the quality of the screenplay.

3. Rushmore was not the first time a director appropriated Murray's "type" for a major supporting role outside his usual range. Tim Burton's Ed Wood (1994) cast him as Bunny Breckinridge, the titular filmmaker's flamboyantly gay sidekick. But Murray's over-the-top, one-note portrayal of Breckinridge fails to foreshadow his more nuanced, post-Rushmore roles.

4. See especially the Charlie Rose interview in the Criterion release of Rushmore. In his commentary for Tenenbaums (Criterion), Anderson states that Raleigh St. Clair was written to give Bill Murray a role in the film, and Royal Tenenbaum was written with Gene Hackman in mind.

5. Gilbey emphasizes Murray's role in crafting dialogue for Groundhog Day, inviting his reader to "simply be thankful that Bill Murray exists. Without him, comic improvisation would be a mediocre discipline in which pretty good might be good enough" (22).

6. Interview, Criterion release of Rushmore. 
7. Behind-the-scenes featurette directed by Eric Chase Anderson, available on the Criterion DVD of Rushmore.

8. Eric Chase Anderson featurette, Criterion DVD of Rushmore.

9. See Robé for an examination of fathers in Anderson's films.

10. Robé discusses how class resentment underscores the narrative dynamics in Rushmore (113-15).

11. "The Look Aquatic" featurette, Criterion release of Life Aquatic.

12. Murray's early characters occupy either side of the class spectrum, dividing the downtrodden (e.g., Stripes, Caddyshack, Quick Change, What About Bob?) from the privileged (e.g., Scrooged, Groundhog Day). However, post-Rushmore, Anderson and others (e.g., Sofia Coppola, Jim Jarmusch) have made Murray's persona more consistently connotative of wealth and high social station.

13. Murray also played the protagonist in Jarmusch's Broken Flowers (2005); see Peberdy for an in-depth analysis of this film. In Coffee and Cigarettes (2003), Jarmusch followed a different trend in star casting, turning Murray into an exaggerated version of himself. Murray also "played himself" under very different narrative circumstances in Zombieland (Fleischer, 2009). Other actors have been similarly cast-perhaps most famously Neil Patrick Harris in Harold and Kumar Go to White Castle (Leiner, 2004)_but this approach to casting and cameos does not suit Wes Anderson, who relies on writing extant star personae into thoroughly fictional characters.

14. See also Elsaesser 295.

15. From Albert Maysles's behind-the-scenes documentary accompanying the Criterion DVD of Tenenbaums.

16. Interview with Bill Murray, Criterion release of Tenenbaums.

17. "Building a Scene" featurette, Criterion release of Life Aquatic.

18. See Corrigan 40.

19. Director commentary track on the Criterion release of Life Aquatic.

20. Universal dual DVD/Blu-Ray release. No word on whether Moonrise Kingdom will eventually get the Criterion treatment, but this release shows that other labels have recognized the benefit of DVD extras. For a discussion of the significance of DVD releases and the extras they contain, see Elsaesser 286.

21. Murray will appear in Anderson's The Grand Budapest Hotel, set for a 2014 theatrical release.

\section{Works Cited}

Corrigan, Timothy. "Auteurs and the New Hollywood." In The New American Cinema, edited by Jon Lewis, 38-63. Durham, NC: Duke UP, 1998. Print.

Elsaesser, Thomas. "Auteurism Today: Signature Products, Concept-Authors and Access for All: Avatar." In The Persistence of Hollywood, 281-304. New York: Routledge, 2012. Print.

Gehring, Wes D. Personality Comedians as Genre: Selected Players. Westport, CT: Greenwood Press, 1997. Print. 
Gilbey, Ryan. Groundhog Day. BFI Modern Classics. London: BFI, 2004. Print. MacDowell, James. "Wes Anderson, Tone and the Quirky Sensibility." New Review of Film and Television Studies 10.1 (March 2012): 6-27. Print.

Orgeron, Devin. "La Camera-Crayola: Authorship Comes of Age in the Cinema of Wes Anderson." Cinema Journal 46.2 (Winter 2007): 40-65. Print.

Peberdy, Donna. Masculinity and Film Performance: Male Angst in Contemporary American Cinema. Basingstoke, UK: Palgrave Macmillan, 2011. Print.

Robé, Chris. "Because I Hate Fathers, and I Never Wanted to Be One': Wes Anderson, Entitled Masculinity, and the 'Crisis' of the Patriarch." In Millennial Masculinity: Men in Contemporary American Cinema, edited by Timothy Shary, 101-121. Detroit, MI: Wayne State UP, 2012. Print.

Ryzik, Melena. "Golden Globes, Before and After." New York Times, January 14, 2013. Web. January 14, 2013.

Shone, Tom. "Bill Murray: Actor, Hipster, Genius, FDR ... God." Guardian December 7, 2012. Web. December 12, 2012.

Thomas, Deborah J. "Framing the 'Melancomic': Character, Aesthetics, and Affect in Wes Anderson's Rushmore." New Review of Film and Television Studies 10.1 (Mar 2012): 97-117. Print. 